\title{
Studi Variasi Morfologi Jenis Rotan Penghasil Jernang (Daemonorops spp.) Di Kecamatan Kuta Panang Kabupaten Aceh Tengah
}

(Morphological Variation Study of Resin Producing Rattan of 'Jernang' (Daemonorops spp.) in Subdistrict Kuta Panang, Middle Aceh)

\author{
Sendy Naya Putri ${ }^{1}$, Saida Rasnovi ${ }^{2}$, Rita Andini ${ }^{3 *}$ \\ ${ }^{1}$ Program Studi Kehutanan PSDKU Unsyiah Gayo Lues, Universitas Syiah Kuala \\ ${ }^{2}$ Program Studi Kehutanan, Fakultas Pertanian, Universitas Syiah Kuala \\ ${ }^{3}$ Program Studi Kehutanan, Fakultas Pertanian, Universitas Syiah Kuala \\ *Corresponding author: andinijapan@yahoo.com
}

\begin{abstract}
Abstrak. Kuta Panang merupakan salah satu Kecamatan yang ada di Kabupaten Aceh Tengah, Provinsi Aceh, Indonesia. Desa Weh Nongkal Toa adalah salah satu desa yang berada di Kecamatan Kuta Panang dengan Luas wilayah desa Weh Nongkal Toa adalah \pm 19.000 ha. Penelitian ini bertujuan untuk mengidentifikasi karakter-karakter morfologi jenis rotan penghasil jernang Daemonorops spp. dan menganalisis dan membandingkan perbedaan yang signifikan pada karakter morfologi jenis rotan penghasil jernang Daemonorops spp. Objek penelitian adalah rotan penghasil jernang (Daemonorops spp.) terdiri dari tiga jenis yaitu Daemonorops draco (Wild.) Blume, Daemonorops mattanensis Becc, Daemonorops didymophylla Becc. Metode yang digunakan dalam penelitian ini yaitu menggunakan variabel penelitian data kualitatif dan kuantitatif yang didalamnya terdapat karakter morfologi pada, 1). batang; (posisi tegak, tinggi batang, diameter batang, jumlah batang, panjang tandan, warna batang, panjang ruas (internode). 2). daun; (panjang daun, jumlah daun, warna daun). 3). buah; (warna buah, diameter buah, jumlah buah). 4). duri; (posisi duri, panjang duri terpendek, panjang duri terpanjang, warna duri). Analisis ANOVA digunakan sebagai alat analisis untuk menguji hipotesis penelitian adakah perbedaan rata-rata antara kelompok dan uji Bnt untuk mendapatkan hasil beda nyata terkecil. Hasil data kuantitatif pada tinggi batang: D. draco 4 - $6 \mathrm{~m}$, D. mattanensis $2-4 \mathrm{~m}, D$. didymophylla 1 - $3 \mathrm{~m}$, panjang tandan yaitu $D$. draco 3 - $4 \mathrm{~m}$, D. mattanensis 1 - 3 m, dan D. didymophylla 1 - $2 \mathrm{~m}$. Diameter batang: D. draco $6-8 \mathrm{~cm}$, D. mattanensis $3-6 \mathrm{~cm}$, dan D. didymophylla $1-3 \mathrm{~cm}$. Panjang ruas: D. draco $15-40 \mathrm{~cm}, D$. mattanensis $10-35 \mathrm{~cm}$ dan $D$. didymophylla 8 - $30 \mathrm{~cm}$. Panjang daun: D. draco 30 - $45 \mathrm{~cm}$, D. mattanensis $30-38 \mathrm{~cm}$, dan D. didymophylla $26-30 \mathrm{~cm}$. Diameter buah: D. draco $4-6 \mathrm{~cm}, D$. mattanensis $2-4 \mathrm{~cm}$, dan D. didymophylla 2 - $3 \mathrm{~cm}$. Panjang duri panjang: D. draco $2-4 \mathrm{~cm}, D$. mattanensis $2-3 \mathrm{~cm}$, dan D. didymophylla $1-2 \mathrm{~cm}$. Uji ANOVA yang berbeda signifikan yaitu pada karakter morfologi kuantitatif tinggi batang, panjang diameter batang, panjang tandan, panjang ruas (internode), panjang daun, dan diameter buah menunjukkan hasil yang berbeda signifikan antara ketiga jenis rotan penghasil jernang (Daemonorops spp.), sedangkan karakter morfologi pada jumlah batang, jumlah daun, jumlah buah, panjang duri terpendek, dan panjang duri terpanjang menunjukkan hasil yang tidak berbeda signifikan antara ketiga jenis Daemonorops spp. Uji BNt yang sangat nyata yaitu pada karakter morfologi kuantitatif tinggi batang, diameter batang, panjang tandan, panjang ruas (internode), panjang daun, dan diameter buah.
\end{abstract}

Kata kunci : Daemonorops spp, Morfologi jenis rotan penghasil jernang dan Kuta Panang Kabupaten Aceh Tengah 
Abstract. Kuta Panang is one of the sub-districts in Central Aceh Regency, Aceh Province, Indonesia. Weh Nongkal Toa Village is one of the villages located in Kuta Panang District with an area of $\pm 19,000$ ha of Weh Nongkal Toa village. This study aims to identify the morphological characters of the rattan species Daemonorops spp and to analyze and compare the significant differences in the morphological characters of Daemonorops spp. The object of the research was the rattan producing jernang (Daemonorops spp.) Which consisted of three types, namely Daemonorops draco (Wild.) Blume, Daemonorops mattanensis Becc, Daemonorops didymophylla Becc. The method used in this study is to use qualitative and quantitative data research variables in which there are morphological characters in, 1). stem; (upright position, stem diameter, stem height, number of stems, bunch length, stem color, internode length. 2). leaf; (leaf length, number of leaves, leaf color). 3). fruit; (fruit color, fruit diameter, number of fruits). 4). thorns; (thorn position, shortest thorn length, longest thorn, thorn color). ANOVA analysis was used as an analytical tool to test the research hypothesis whether there was an average difference between groups and the Bnt test to obtain the smallest significant difference. The results of quantitative data on stem height: D. draco 4 - $6 \mathrm{~m}$, D. mattanensis 2 - 4 m, D. didymophylla 1 - 3 m, bunch length namely D. draco 3 - 4 m, D. mattanensis 1 - 3 $m$, and D. didymophylla $1-2 \mathrm{~m}$. Stem diameter: D. draco $6-8 \mathrm{~cm}$, D. mattanensis $3-6 \mathrm{~cm}$, and D. didymophylla $1-3 \mathrm{~cm}$. Internode lengths: D. draco $15-40 \mathrm{~cm}, \mathrm{D}$. mattanensis $10-35 \mathrm{~cm}$ and D. didymophylla $8-30 \mathrm{~cm}$. Leaf length: D. draco 30-45 cm, D. mattanensis $30-38 \mathrm{~cm}$, and D. didymophylla 26 - $30 \mathrm{~cm}$. Fruit diameter: D. draco 4 - $6 \mathrm{~cm}$, D. mattanensis 2 - $4 \mathrm{~cm}$, and D. didymophylla 2 - $3 \mathrm{~cm}$. Long spines: D. draco 2 - $4 \mathrm{~cm}$, D. mattanensis $2-3 \mathrm{~cm}$, and D. didymophylla $1-2 \mathrm{~cm}$. ANOVA test that was significantly different, namely the quantitative morphological characters of stem height, stem diameter length, bunch length, internode length, leaf length, and fruit diameter showed significantly different results between the three types of rattan producing jernang (Daemonorops spp.), Whereas Morphological characters on the number of stems, number of leaves, number of fruits, length of the shortest thorn, and length of the longest thorn showed no significant difference between the three types of Daemonorops spp. The very real Bnt test was the quantitative morphological character of stem height, stem diameter, bunch length, internode length, leaf length, and fruit diameter.

Keywords: Daemonorops spp, Morphology of types of rattan producing jernang and Kuta Panang, Central Aceh Regency

\section{PENDAHULUAN}

Morfologi tumbuhan adalah ilmu yang mempelajari bentuk dan susunan tumbuhan yang dipisahkan menjadi morfologi luar, yaitu anatomi tumbuhan. Selain itu morfologi harus pula dapat memberikan jawaban atas pertanyaan mengapa bagian-bagian tubuh tumbuhan mempunyai bentuk dan susunan yang beranekaragam itu (Tjitrosoepomo, 2005). Hasil Hutan Bukan Kayu (HHBK) adalah hasil hutan hayati baik nabati maupun hewani beserta produk turunannya dan budidaya kecuali kayu yang berasal dari hutan (Peraturan Menteri Kehutanan No P. 35/Menhut-II/2007).

Kegiatan pemanenan dan pengolahan HHBK dapat memberikan pekerjaan dan pendapatan musiman bagi masyarakat dan mengurangi 30\% ketidaksetaraan pendapatan. (John. 2005). Di Indonesia genus Daemonorops terdiri dari banyak spesies yaitu 115 spesies (Rustiami et. al, 2004). Daemonorops yang terdiri dari 115 spesies yang ditemukan di Indonesia, 12 spesies menghasilkan getah, yaitu $D$. acehensis, D. brachystachys, $D$. didymophylla, $D$. draco, $D$, dracuncula, $D$. dransfieldii. D. maculata, D. micracantha, $D$. rubra, D. sekundurensis, D. siberutensis, dan D. uschdraweitiana.

Jernang digunakan dalam ilmu pengobatan tradisional cina kuno dan sebagai bahan obat-obatan untuk diare, sebagai obat luka, obat asma, anti-ulcer, dan anti-tumor, serta agent aktif untuk pembekuan darah, juga untuk pengobatan pendarahan didalam (Grieve 
2006 dalam Waluyo, 2008). Pemanfaatan jernang oleh masyarakat dilakukan dengan cara memanen buah yang sudah matang rotan yang didapat dari hutan. Buah jernang matang lebih diutamakan di karenakan kadar resin akan berkurang dengan semakin tuanya buah.

Potensi jernang di Aceh cukup tinggi dan memiliki nilai ekonomi tinggi dengan nilai jual seharga hampir Rp 400.000/kg di tingkat petani dan Rp 2 juta/kg jika sudah diolah sebagai tepung. Namun saat ini, degradasi dan konversi hutan mengakibatkan populasi rotan jernang menurun. Hingga saat ini, belum ada penelitian terkait dengan studi variasi morfologi jenis rotan penghasil jernang (Daemonorops spp.) khususnya di Kabupaten Aceh Tengah. Tujuan utama dari penelitian ini adalah untuk mengidentifikasi, menganalisis dan membandingkan perbedaan karakter morfologi jenis rotan penghasil jernang (Daemonorops spp.) secara langsung di lapangan.

\section{METODE PENELITIAN}

\section{Lokasi}

Lokasi penelitian dilakukan di Kecamatan Kuta Panang, Takengon, Kabupaten Aceh Tengah, Provinsi Aceh.

\section{Alat dan Bahan}

Alat yang digunakan adalah kamera HP jenis Oppo A5s tahun 2019 untuk mengambil semua dokumentasi gambar kegiatan penelitian, alat tulis dan buku lapangan untuk mencatat semua hasil penelitian, pita meteran (ukuran max. $20 \mathrm{~m}$.) untuk pengukuran data morfologi, sasag/press kayu berukuran 30 × $50 \mathrm{~cm}$ untuk pengepresan herbarium untuk membuat spesimen tumbuhan, parang, pengait, sarung tangan untuk melindungi tangan, ovenuntuk mengeringkan spesimen herbarium. Bahan yang digunakan adalah tally sheet, kertas label, koran bekas, benang jagung, kertas kardus, alkohol $70 \%$.

\section{Cara Kerja}

Prosedur penelitian dilakukan dengan metode acak dan pengamatan karakter morfologi merupakan modifikasi dari (Himmah Rustiami, 2014) meliputi a). Batang; (posisi batang, diameter batang, tinggi batang, jumlah batang per rumpun, panjang ruas (internode), warna batang), b) Tandan; (jumlah tandan, panjang tandan), c). Daun; (panjang daun, jumlah daun, warna daun). d). Buah; (warna buah, diameter buah, jumlah buah). e). Duri; (posisi duri, panjang duri terpendek, panjang duri terpanjang, warna duri). Analisis data kuantitatif menggunakan analisis ANOVA satu arah dan uji lanjut Beda Nyata terkecil (BNt) untuk mendapatkan perbedaan morfologi antara tiga spesies rotan penghasil jernang (Daemonorops spp.). 
Uji ANOVA satu jalur (One Way Anova) analisis varians satu jalur merupakan teknik statistika parametrik yang digunakan untuk pengujian perbedaan beberapa kelompok rata-rata, dimana hanya terdapat satu variabel bebas atau independen yang dibagi dalam beberapa kelompok dan satu variabel terikat atau independen.

\section{Parameter dan Analisis Data}

Parameter penelitian adalah karakter morfologi 1). batang; (posisi tegak, tingi batang, diameter batang, jumlah batang, jumlah tandan, panjang tandan, warna batang, panjang ruas (internode). 2). daun; (panjang daun, jumlah daun, warna daun). 3). buah; (warna buah, diameter buah, jumlah buah). 4). duri; (posisi duri, panjang duri terpendek, panjang duri terpanjang, warna duri). Analisis data dilakukan dengan menggunakan :

- Data Kuantitatif

Analisis data kuantitatif menggunakan analisis ANOVA satu arah dan uji lanjut Beda Nyata terkecil (BNt) untuk mendapatkan perbedaan morfologi antara tiga spesies rotan penghasil jernang (Daemonorops spp.)

\section{- Data Kualitatif}

Analisis data kualitatif dilakukan dari sumber jurnal-jurnal dan literatur secara deskriptif yang bersifat deskripsi dan menggambarkan apa adanya data yang disajikan dalam uraian kata-kata.

- Anova

Analisis varians (analysis of variance, ANOVA) adalah suatu metode analisis statistika yang termasuk ke dalam cabang statistika inferensi.

$H^{0}: \mu 1=\mu 2 \ldots=\mu k$

- Seluruh mean populasi adalah sama

- Tak ada efek treatment (tak ada keragaman mean dalam grup)

$\mathbf{H}^{1}$ : tidak seluruh mean populasi adalah sama

- Minimal ada 1 mean populasi yang berbeda

- Terdapat seluruh efek treatment

- Tidak seluruh mean populasi berbeda (beberapa pasang mungkin sama)

- Uji Lanjut BNt

Menurut Sastrosupadi (2000) uji beda nyata terkecil dilakukan untuk mengetahui perbedaan masing-masing perlakuan atau beda nyata antar perlakuan dengan taraf nyata $5 \%$ dapat dihitung dengan rumus:

$$
\mathrm{sd}=\sqrt{ } 2 * K T G / \mathrm{r}
$$

Dimana:

- sd : standar deviasi

- KT : Kuadrat Tengah

- G : Galat (sampling error)

- $r$ : Ulangan (ada berapa kali pengulangan) 


\section{HASIL DAN PEMBAHASAN}

\section{Karakter Morfologi Daemonorops draco (Wild.) Blume}

Dari hasil penelitian variasi morfologi jenis rotan penghasil jernang di Kecamatan Kuta Panang Kabupaten Aceh Tengah, rotan penghasil jernang Daemonorops draco (Wild.) Blume diberi nama lokal yaitu rotan jernang super. Rotan jernang ini memiliki; a). karakter batang yang terdiri dari tinggi batang yaitu $4-6 \mathrm{~m}$ tumbuh tegak ke atas dan memiliki perawakan (habitus) liana tumbuh memanjat dan berkerumun. Diameter batang yaitu $6-8 \mathrm{~cm}$ dan terdapat $6-10$ batang per rumpun, memiliki panjang tandan $3-4 \mathrm{~m}$. Warna batang yaitu kuning dan memiliki panjang ruas (internode) $15-40 \mathrm{~cm}$ per batang. b). karakter daun yang terdiri dari panjang daun yaitu $30-45 \mathrm{~cm}$ dan terdapat $60-70$ jumlah daun per batang, serta daun rotan penghasil jernang jenis ini memiliki warna hijau. c). karakter buah yang terdiri dari jenis rotan penghasil jernang super ini memiliki karakter buah yang perawakannya (habitus) berkerumun, diameter buahnya $4-6 \mathrm{~cm}$, memiliki warna kulit buah coklat gelap mengkilat dengan sisik buah yang cembung dan jumlah buah yaitu 20 - 40 per tandan. d). karakter duri yang terdiri dari posisi duri tersebar pada batang dan terdapat duri juga pada tangkai daun. Panjang duri terpendek yaitu $1-2 \mathrm{~cm}$ dan panjang duri terpanjang $2-4 \mathrm{~cm}$ serta memiliki warna duri kuning kecoklatan.

\section{Karakter Morfologi Daemonorops mattanensis Becc.}

Dari hasil penelitian variasi morfologi jenis rotan penghasil jernang di Kecamatan Kuta Panang Kabupaten Aceh Tengah, rotan penghasil jernang Daemonorops mattanensis Becc. diberi nama lokal yaitu rotan jernang gajah. Rotan jernang ini memiliki; a). Karakter batang yang terdiri dari tinggi batang yaitu $2-4 \mathrm{~m}$ yang tumbuh tegak ke atas dan memiliki perawakan (habitus) liana tumbuh memanjat dan berkerumun. Diameter batang yaitu 3 - $6 \mathrm{~cm}$ dan terdapat $4-8$ batang per rumpun, dan memiliki panjang tandan $1-3 \mathrm{~m}$. Warna batang yaitu coklat kehijauan dan memiliki panjang ruas (internode) $10-35 \mathrm{~cm}$ per batang. b). Karakter daun yang terdiri dari panjang daun yaitu $30 \mathrm{~cm}$ dan terdapat 60 jumlah daun per batang, serta daun jenis ini memiliki warna hijau. c). Karakter buah yang terdiri dari jenis rotan penghasil jernang super ini memiliki karakter buah yang perawakannya (habitus) berkerumun, diameter buahnya $2-4 \mathrm{~cm}$, memiliki warna kulit buah coklat muda dengan sisik buah yang cembung dan jumlah buah yaitu 18 - 30 per tandan. d). Karakter duri yang terdiri dari jenis rotan penghasil jernang super ini memiliki karakter posisi duri tersebar pada batang dan terdapat duri juga pada tangkai daun. Panjang duri terpendek yaitu $1-2 \mathrm{~cm}$ dan panjang duri terpanjang $2-3 \mathrm{~cm}$ serta memiliki warna duri kecoklatan.

\subsection{Karakter Morfologi Daemonorops didymophylla Becc.}

Dari hasil penelitian variasi morfologi jenis rotan penghasil jernang di Kecamatan Kuta Panang Kabupaten Aceh Tengah, rotan penghasil jernang Daemonorops didymophylla Becc. diberi nama lokal yaitu rotan jernang kacang. Rotan jernang ini di amati dengan memiliki; a). Karakter batang; tinggi batang yaitu 1 - 3 m yang tumbuh tegak ke atas dan memiliki perawakan (habitus) liana tumbuh memanjat dan berkerumun. Diameter batang yaitu $1-3 \mathrm{~cm}$ dan terdapat $3-6$ batang per rumpun, dan memiliki 
panjang tandan $1-2 \mathrm{~m}$. Warna batang yaitu hijau dan memiliki panjang ruas (internode) 8 $-30 \mathrm{~cm}$ per batang. b). Karakter daun; panjang daun yaitu $26-30 \mathrm{~cm}$ dan terdapat $60-70$ jumlah daun per batang, serta daun jenis ini memiliki warna hijau. c). Karakter buah; jenis rotan penghasil jernang super ini memiliki karakter buah yang perawakannya (habitus) berkerumun, diameter buahnya $2-3 \mathrm{~cm}$, memiliki warna kulit buah coklat muda dengan sisik buah yang rata dan jumlah buah yaitu 18 - 28 per tandan. d). Karakter duri; jenis rotan penghasil jernang super ini memiliki karakter posisi duri tersebar pada batang dan terdapat duri juga pada tangkai daun. Panjang duri terpendek yaitu $1-2 \mathrm{~cm}$ dan panjang duri terpanjang 1 - $2 \mathrm{~cm}$ serta memiliki warna duri hijau.

\section{Karakter Morfologi Rotan Penghasil Jernang (Daemonorops spp.) Di Kecamatan Kuta Panang Kabupaten Aceh Tengah}

Hasil penelitian morfologi jenis rotan penghasil jernang (Daemonorops spp.) di Kecamatan Kuta Panang Kabupaten Aceh Tengah menunjukkan adanya karakter morfologi bersama yaitu perawakannya liana, tumbuh memanjat dan berumpun (Gambar 1.), warna daun hijau (Gambar 2.), susunan buah bergerombol (Gambar 3.), posisi duri tegak dan memiliki duri pada tangkai daun (Gambar 4.).
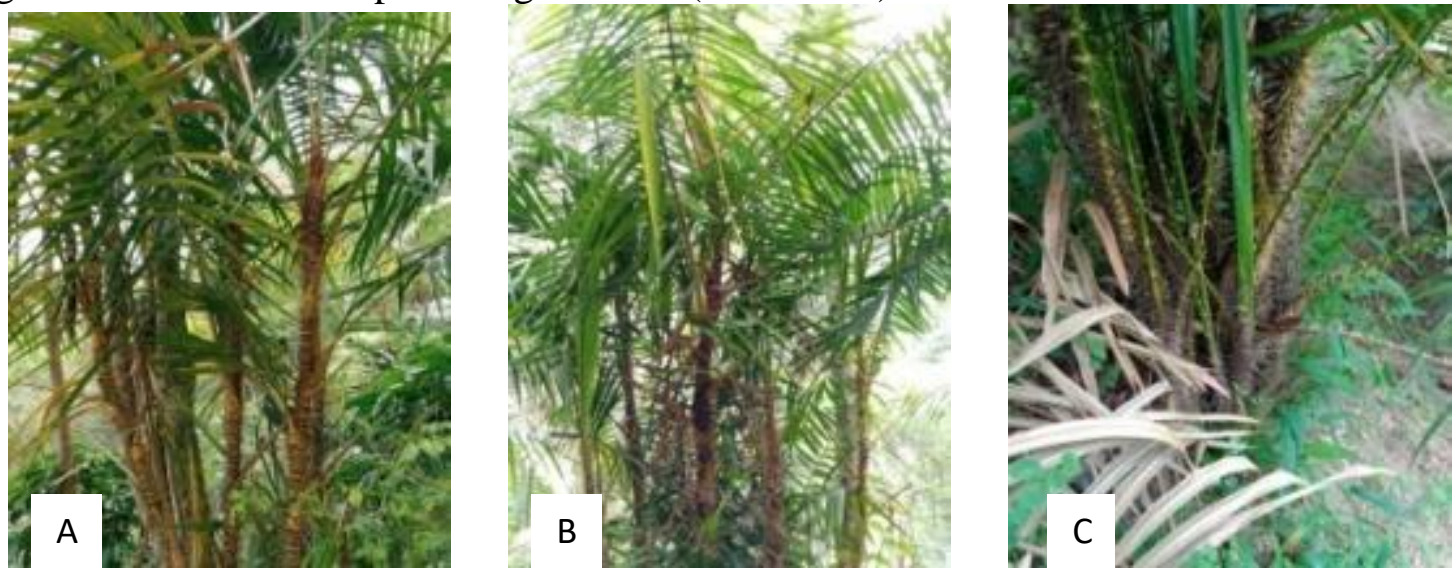

Gambar 1. Perawakan rotan penghasil jernang tumbuh memanjat dan berumpun.

A) Daemonorops draco (Wild.) Blume,

B). Daemonorops mattanensis Becc., C) Daemonorops didymophylla Becc.
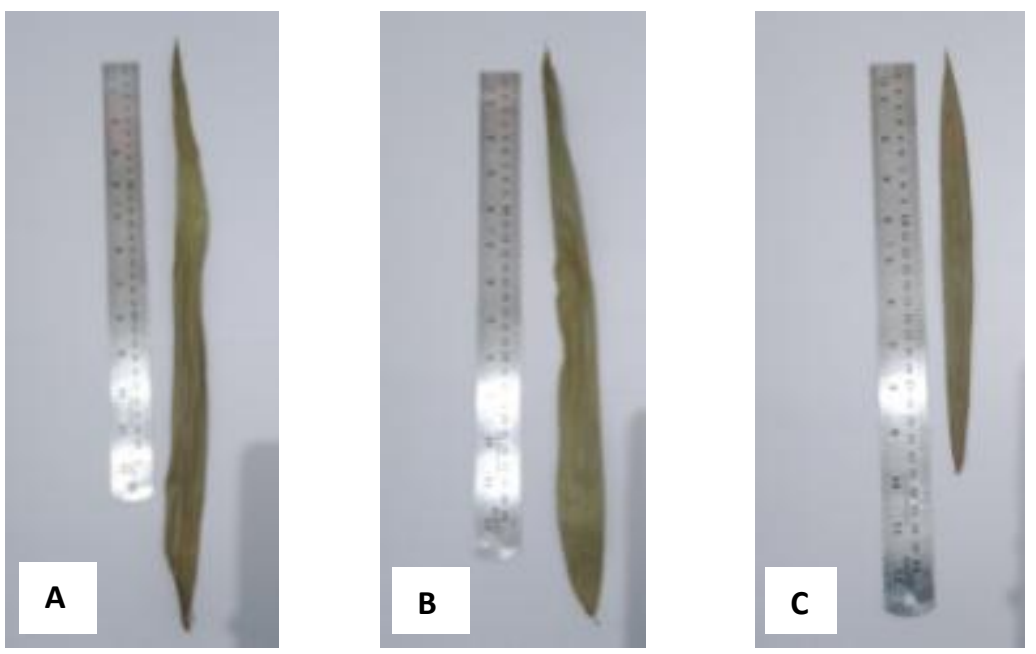


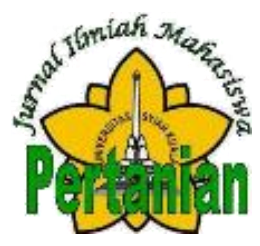

JURNAL ILMIAH MAHASISWA PERTANIAN

E-ISSN: 2614-6053 P-ISSN: 2615-2878

Volume 5, Nomor 4, November 2020 www.jim.unsyiah.ac.id/JFP

Gambar 2. Warna daun rotan penghasil jernang.

A). Daemonorops draco (Wild.) Blume,

B). Daemonorops mattanensis Becc., C). Daemonorops didymophylla Becc.
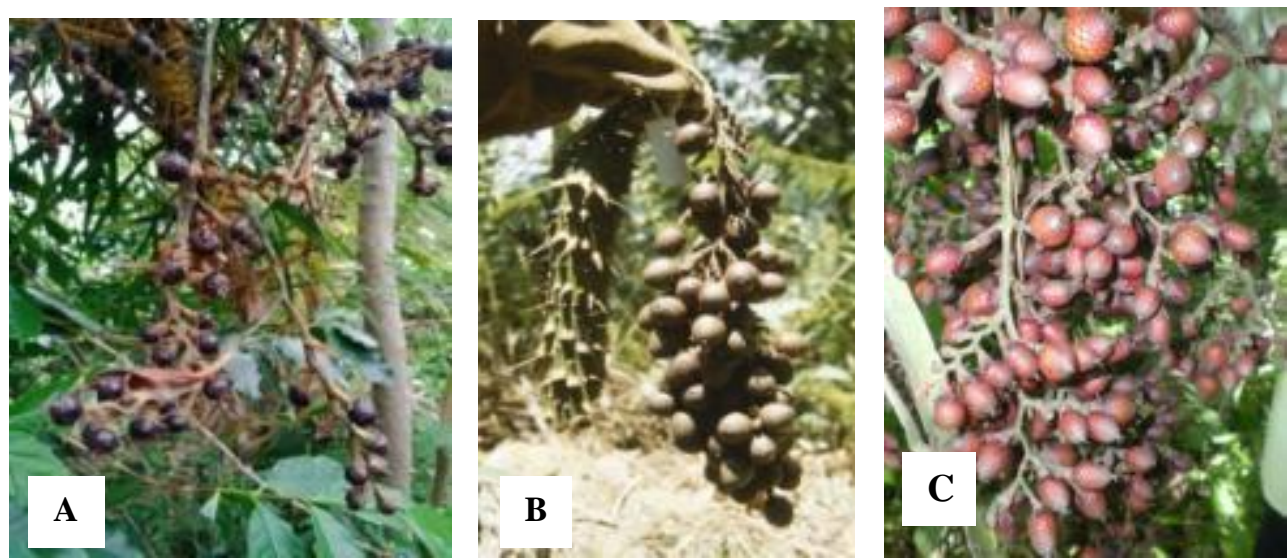

Gambar 3. Susunan buah rotan penghasil jernang bergerombol.

(Daemonorops spp.)

A). Daemonorops draco (Wild.) Blume,

B). Daemonorops mattanensis Becc., C). Daemonorops didymophylla Becc.
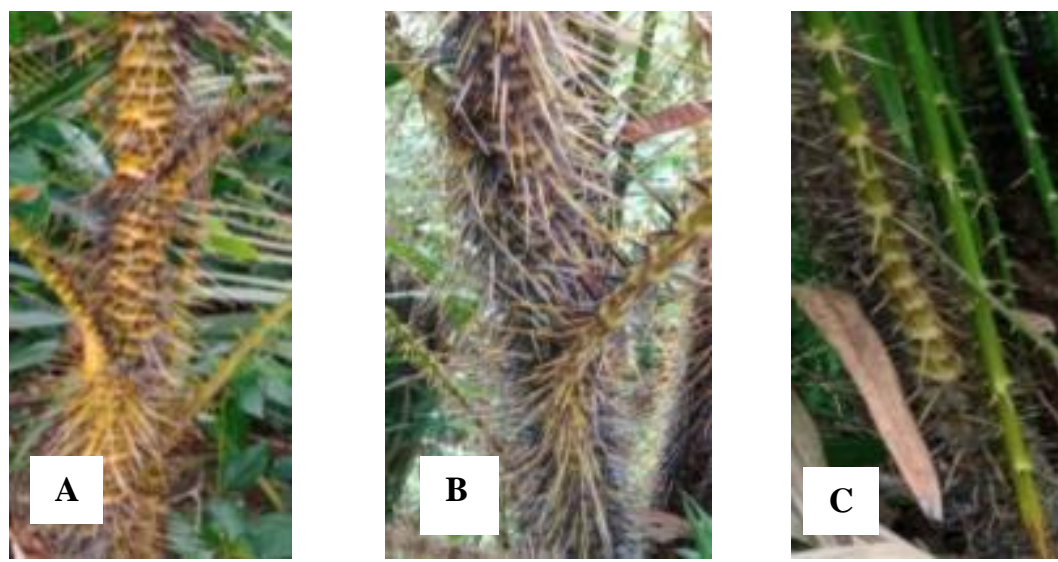

Gambar 4. Posisi duri rotan penghasil jernang berbentuk tegak dan terdapat ditangkai daun. A). Daemonorops draco (Wild.) Blume,

B). Daemonorops mattanensis Becc., C). Daemonorops didymophylla Becc.

\section{Perbandingan Karakter Morfologi Jenis Rotan Penghasil Jernang (Daemonorops spp.) di Desa Jebak Kabupaten Batanghari Provinsi Jambi}

Desa Jebak Kabupaten Batanghari Jambi, juga ditemukan tiga spesies rotan penghasil jernang yaitu Daemonorops didymophylla, Daemonorops draco, dan Daemonorops mattanensis. Berdasarkan informasi dari pencari getah jernang Suku Anak Dalam desa Jebak, masyarakat hanya mengenal dua spesies penghasil getah jernang yaitu rotan jernang (Daemonorops draco) dan rotan mengkarung/kelemunting (Daemonorops didymophylla). Spesies rotan jernang (Daemonorops draco) mempunyai kualitas getah 
jernang lebih baik dan harganya lebih mahal dibandingkan dengan getah jernang mengkarung/kelemunting/kelukup (Daemonorops didymophylla). Selain itu, rotan jernang juga memiliki buah yang lebih hitam, untaian bunga lebih panjang, susunan bunga rapat, sedangkan rotan mengkarung/kelemunting/kelukup untaian bunganya lebih pendek dan kandungan getah jernangnya sedikit.

\section{Perbandingan Karakter Morfologi Jenis Rotan Penghasil Jernang (Daemonorops spp.)}

Hasil penelitian variasi morfologi jenis rotan penghasil jernang (Daemonorops spp.) dii Kecamatan Kuta Panang Kabupaten Aceh Tengah, perbandingan karakter morfologi dibedakan menjadi dua yaitu data morfologi kualitatif dan data morfologi kuantitatif.

\section{Analisis Data Karakter Morfologi Kualitatif Jenis Rotan Penghasil Jernang (Daemonorops spp.)}

Sebanyak 10 karakter kualitatif yang berhasil dicatat yaitu ada 5 karakter morfologi yang memiliki persamaan dan ada 4 karakter morfologi yang berbeda (Tabel 1.). Yang berbeda antara D. draco, D. mattanensis dan D. didymophylla ini adalah pada karakter warna batang, warna buah, sisik buah, dan warna duri yang dapat dilihat pada Gambar 5, Gambar 6. dan Gambar 7.

Tabel 1. Data kualitatif karakter morfologi rotan penghasil jernang (Daemonorops spp.)

\begin{tabular}{|c|c|c|c|c|}
\hline \multirow[b]{2}{*}{ No } & \multirow[b]{2}{*}{ Karakter } & \multicolumn{3}{|c|}{ Jernang Daemonorops spp. } \\
\hline & & A. Draco & D. mattanensis & D. didymophylla \\
\hline 1. & Perawakan (habitus) & Berumpun & Berumpun & Berumpun \\
\hline 2. & Warna batang & Kuning & Coklat kehijauan & Hijau \\
\hline 3. & Warna daun & Hijau & Hijau & Hijau \\
\hline 4. & Susunan buah & Bergerombol & Bergerombol & Bergerombol \\
\hline 5. & Warna buah & Coklat gelap & Coklat muda & Coklat muda \\
\hline 6. & Sisik buah & Cembung & Cembung & Rata \\
\hline 7. & Posisi duri & $\begin{array}{l}\text { Tegak } 90^{\circ} \text { dari } \\
\text { permukaan tanah }\end{array}$ & $\begin{array}{l}\text { Tegak } 90^{\circ} \text { dari } \\
\text { permukaan tanah }\end{array}$ & $\begin{array}{l}\text { Tegak } 90^{\circ} \text { dari } \\
\text { permukaan tanah }\end{array}$ \\
\hline 8. & $\begin{array}{l}\text { Duri pada tangkai } \\
\text { daun }\end{array}$ & Ada & Ada & Ada \\
\hline 9. & Warna duri & Kuning kecoklatan & Kecoklatan & Hijau \\
\hline
\end{tabular}

Pada tabel di atas terlihat ketiga jenis rotan penghasil jernang Daemonorops spp. perawakannya adalah berumpun. Warna batang berbeda-beda untuk setiap jenis: $D$. draco memiliki warna batang kuning, D. mattanensis memiliki warna batang coklat kehijauan dan $D$. didymophylla memiliki warna batang hijau. 


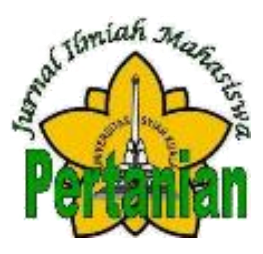

JURNAL ILMIAH MAHASISWA PERTANIAN

E-ISSN: 2614-6053 P-ISSN: 2615-2878

Volume 5, Nomor 4, November 2020 wWw.jim.unsyiah.ac.id/JFP
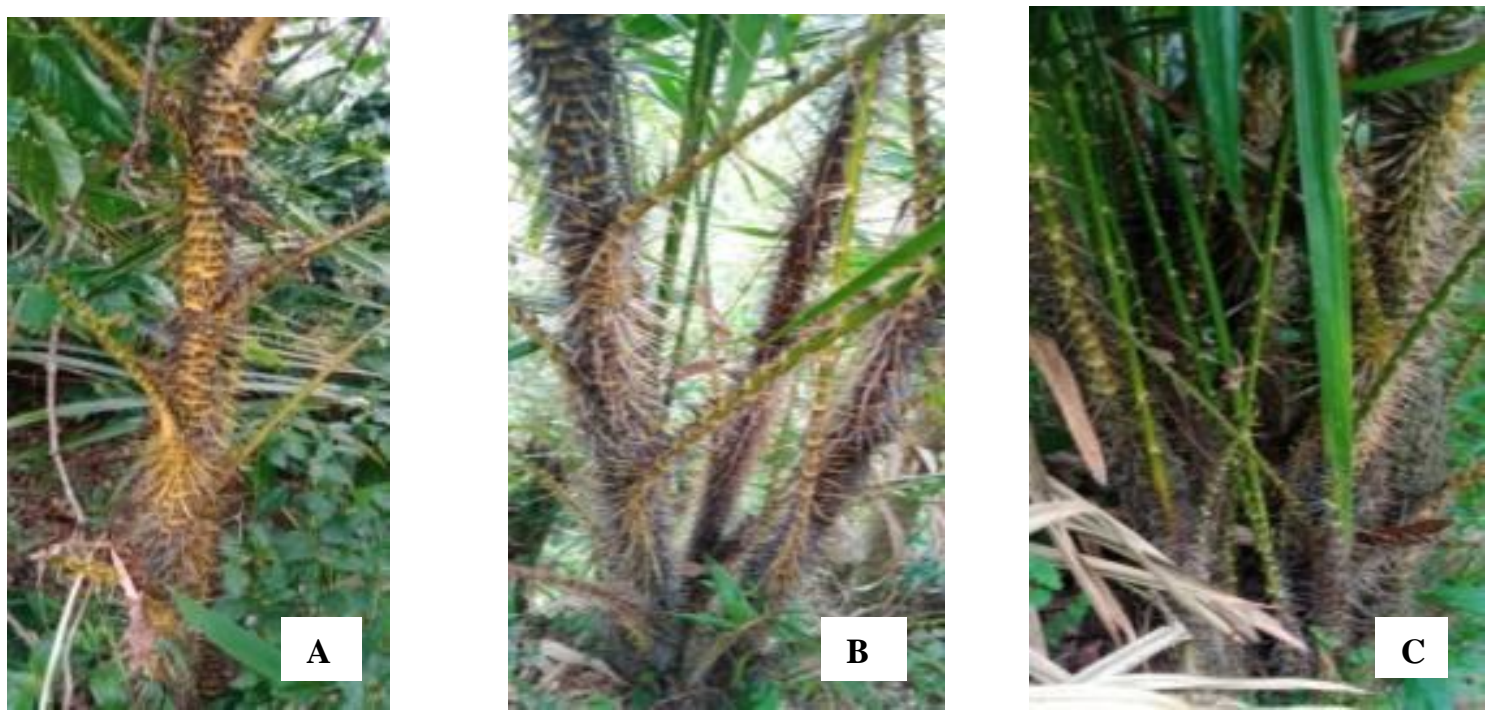

Gambar 5. Warna batang Rotan penghasil jernang.

A). Daemonorops draco (Wild.) Blume,

B). Daemonorops mattanensis Becc., C). Daemonorops didymophylla Becc.

(koleksi pribadi, 2019)

Batang rotan penghasil jernang berbentuk bulat memanjang seperti silinder. Batang rotan penghasil jernang terbagi menjadi ruas-ruas, pelepah dan tangkai daun melekat pada batang. Warna batang rotan penghasil jernang berbeda setiap jenisnya dan duri berwarna hitam menutup seluruh batang, duri akan rontok saat batang rotan akan berbuah. Batang rotan penghasil jernang awalnya tumbuh menyusur tanah untuk mendapatkan ruang untuk tumbuh, setelah mendapat ruang, batang rotan jernang akan tumbuh vertikal ke arah sinar matahari (Januminro, 2000).

Persamaan lainnya, ketiga jenis Daemonorops spp. memiliki warna pada buah yang sama yaitu coklat, akan tetapi untuk jenis Daemonorops draco (Wild.) Blume warna kulit buahnya terlihat coklatnya lebih gelap dan mengkilat, sedangkan untuk Daemonorops mattanensis Becc. Dan Daemonorops didymophylla Becc. memiliki warna coklat muda.
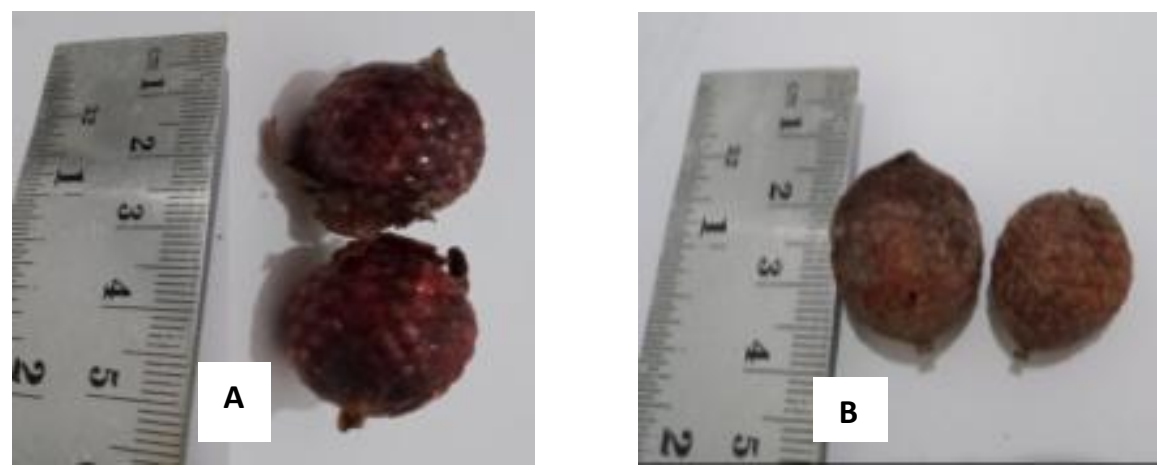


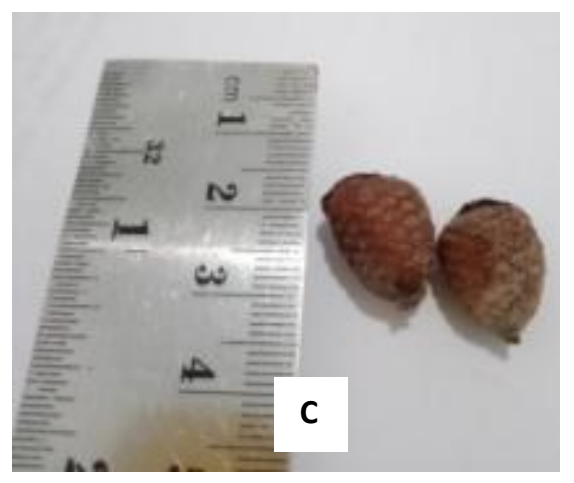

Gambar 6. Warna buah rotan penghasil jernang. A). Daemonorops draco (Wild.) Blume, B). Daemonorops mattanensis Becc., C). Daemonorops didymophylla Becc.

Pemanfaatan buah jernang adalah buah jernang yang belum masak dikarenakan resin yang menempel pada buah banyak dan nilai jual tinggi, hal ini sesuai dengan pernyataan Puspitasari (2012) yang menyatakan bahwa buah yang menghasilkan jernang lebih banyak adalah buah yang tua namun belum masak.

Jenis rotan jernang yang mampu memproduksi resin jernang adalah Daemonorops draco, D. mattanensis, D. didymophylla, dan D. micracantha. Ke empat jenis rotan jernang ini akan mulai berbunga oada umur tanaman 2 - 3 tahun dan berbuah antara 4 - 6 tahun (Sumarna, 2004).

Susunan buah untuk ketiga jenis adalah bergerombol, akan tetapi warna buahnya berbeda. Buah $D$. draco berwarna coklat gelap dan mengkilat, sedangkan $D$. mattanensis dan $D$. didymophylla memiliki warna coklat muda. Jernang $D$. draco dan $D$. mattanensis memiliki karakter sisik buah yang cembung sedangkan $D$. didymophylla sisik buahnya rata. Hal ini sesuai dengan pernyataan Januminro (2000), buah rotan penghasil jernang berwarna coklat mengkilat dan apabila resin pada kulit buah sudah diekstrak maka kulit buah jernang tampak bersisik seperti buah salak, apabila kulit buah dikupas terdapat daging buah dan apabila daging buah dikupas terdapat biji rotan jernang. Buah rotan penghasil jernang terdiri atas kulit luar berupa sisik yang berbentuk trapesium dan tersusun secara vertikal dari toksis buah. Ukuran sisik bervariasi, tergantung pada ukuran buah, makin besar ukuran buah, makin besar pula ukuran sisiknya. Bentuk permukaan buah rotan jernang kasar terdapat resin, dan bentuk buah rotan jernang pada umumnya bulat telur atau lonjong. Kulit buah yang sudah masak berwarna coklat, coklat kemerah-merahan. Berdasarkan Matangaran dan Puspitasari (2012), satu batang dapat menghasilkan lima sampai enam tandan buah dan pada musim panen umumnya hanya ada tiga tandan buah saja

Warna duri semua jenis Daemonorops spp. memiliki perbedaan yaitu $D$. draco kuning kecoklatan, D. mattanensis Becc. kecoklatan dan D. didymophylla Becc. hijau. 

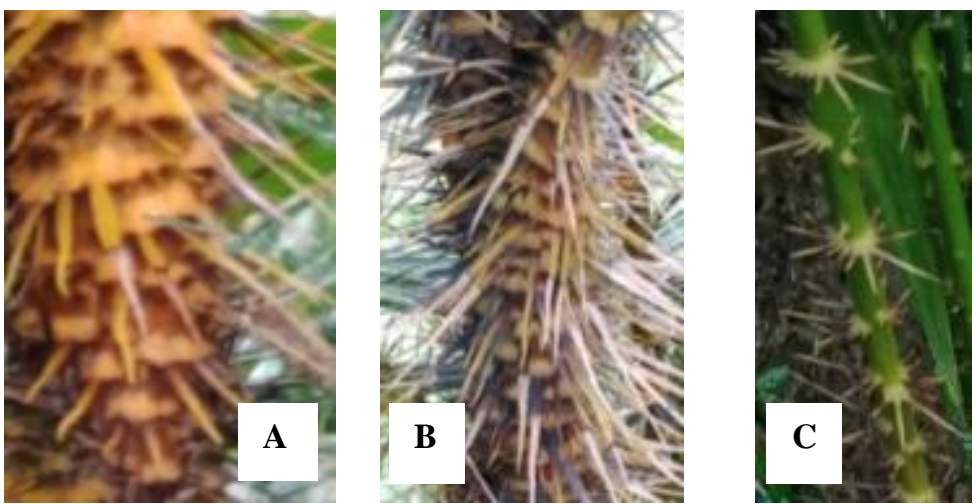

Gambar 7. Warna duri rotan penghasil jernang.

A). Daemonorops draco (Wild.) Blume,

B). Daemonorops mattanensis Becc., C). Daemonorops didymophylla Becc.

Gafar P.A (2010), menyebutkan bahwa duri rotan penghasil jernang berposisi tegak mengarah ke luar, tumbuh pada bagian pangkal batang dan pelepah batang, terbentuk sebagai bagian dari kelengkapan pelindungan batang rotan jernang. Apabila rotan jernang telah dewasa dan akan berbuah, pelepah duri pada pangkal batang akan tanggal.

\section{Analisis Data Karakter Morfologi Kuantitatif Rotan Penghasil Jernang}

Sebanyak 11 karakter kuantitatif yang berhasil dicatat yaitu ada 2 karakter morfologi dengan satuan meter $(\mathrm{m})$ yaitu tinggi batang dan panjang tandan, 6 karakter morfologi dengan satuan centimeter $(\mathrm{cm})$ yaitu diameter batang, panjang ruas, panjang daun, diameter buah, panjang duri terpendek dan panjang duri terpanjang, dan yang terakhir 3 karakter morfologi yaitu jumlah batang (per rumpun), jumlah daun (per batang), dan jumlah buah (per tandan) yang dapat dilihat pada tabel 2.

Tabel 2. Data kuantitatif karakter morfologi rotan penghasil jernang (Daemonorops spp.)

\begin{tabular}{llccc}
\hline & & \multicolumn{3}{c}{ Jernang Daemonorops spp. } \\
\cline { 3 - 5 } No. & \multicolumn{1}{c}{ Karakter } & D. draco & D. mattanensis & D. didymophylla \\
\hline 1. & Tinggi batang (m) & $4-6$ & $2-4$ & $1-3$ \\
2. & Diameter batang (cm) & $6-8$ & $3-6$ & $1-3$ \\
3. & Jumlah batang (per & $6-10$ & $4-8$ & $3-6$ \\
& rumpun) & & & \\
4. & Panjang tandan (m) & $3-4$ & $1-3$ & $1-2$ \\
5. & Panjang ruas (internode) & $15-40$ & $10-35$ & $8-30$ \\
& (cm) & & & \\
6. & Panjang daun (cm) & $30-45$ & $30-38$ & $26-30$ \\
7. & Jumlah daun (per batang) & $60-70$ & $60-70$ & $60-70$ \\
8. & Diameter buah (cm) & $4-6$ & $2-4$ & $2-3$ \\
9. & Jumlah buah (per tandan) & $20-40$ & $18-30$ & $18-28$ \\
10. & Panjang duri terpendek & $1-2$ & $1-2$ & $1-2$ \\
& (cm) & $2-4$ & $2-3$ & $1-2$ \\
11. & Panjang duri terpanjang & & & \\
& (cm) & & & \\
\hline
\end{tabular}


Adapun secara grafik beda karakter morfologi kuantitatif $(\mathrm{m})$ dan $(\mathrm{cm})$ yang dilakukan pada $<10$ sampel jenis rotan penghasil jernang antara D. draco, D. mattanensis, dan D. didymophylla adalah sebagaimana yang terdapat pada Gambar 8 dan Gambar 9.

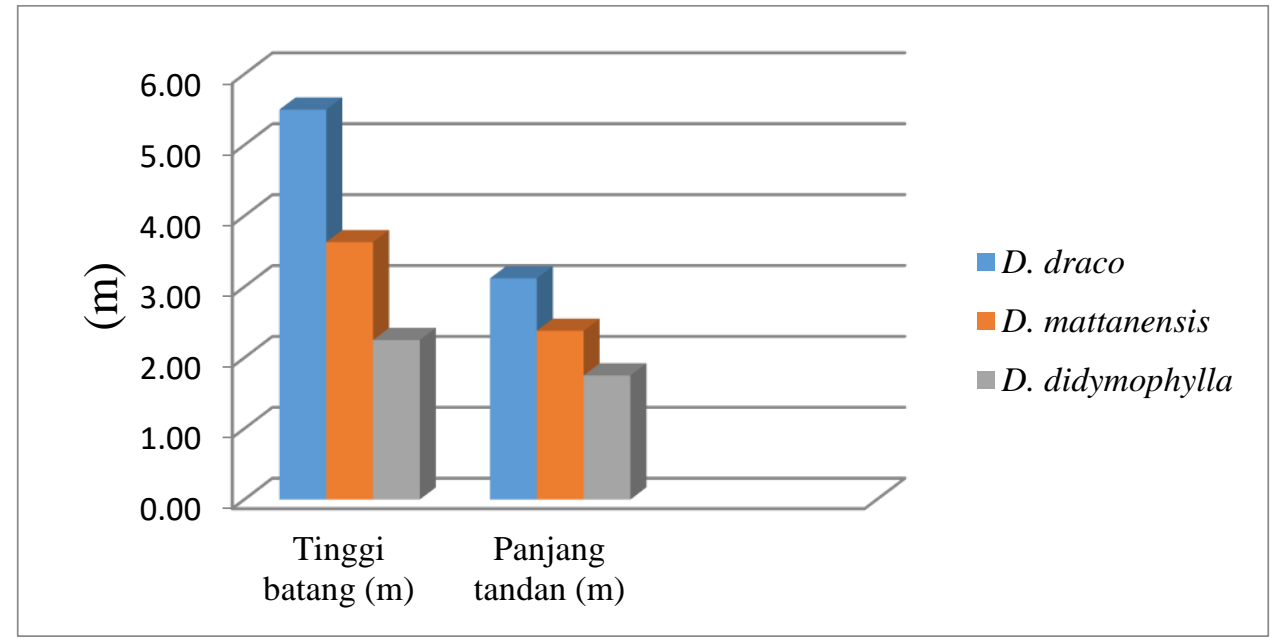

Gambar 8. Grafik nilai rata-rata kuantitatif $(\mathrm{m})$ karakter morfologi ketiga jenis jernang

Hasil data kuantitatif pada grafik diatas terlihat bahwa nilai minimum dan maksimum untuk tinggi batang yang tertinggi adalah $D$. draco $4-6 \mathrm{~m}$ dan yang paling rendah yaitu $D$. didymophylla $1-3 \mathrm{~m}$. Hal ini sesuai dengan pernyataan Rustiami et. al, (2004) dan Winarni et. al, (2004), ciri yang membedakan Daemonorops draco dengan Daemonorops yang lain adalah Daemonorops draco memiliki tinggi batang yang tertinggi yaitu bisa mencapai $4-15 \mathrm{~m}$.

Panjang tandan, dari hasil grafik di atas terdapat data kuantitatif yang dilakukan sebanyak < 10 sampel rotan penghasil jernang dengan hasil pengukuran yang berbeda untuk setiap masing-masing jenis diantaranya yaitu D. draco 3 - $4 \mathrm{~m}$, D. mattanensis 1 - 3 $\mathrm{m}$, dan D. didymophylla 1 - $2 \mathrm{~m}$. 


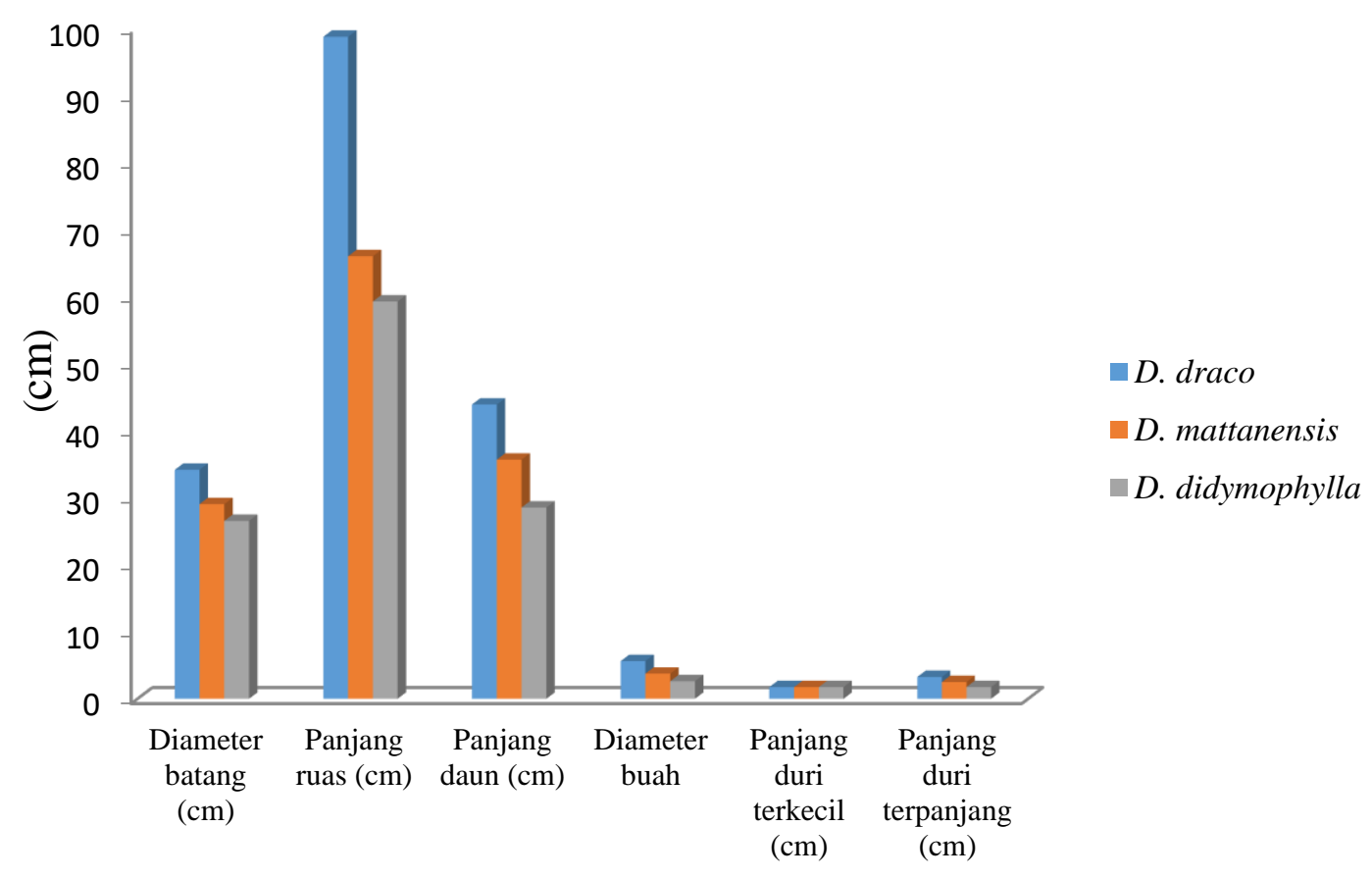

Gambar 9. Grafik nilai rata-rata kuantitatif $(\mathrm{cm})$ karakter morfologi ketiga jenis jernang

Diameter batang, dari hasil grafik di atas terdapat data kuantitatif yang dilakukan sebanyak < 10 sampel rotan penghasil jernang dengan hasil pengukuran yang berbeda untuk setiap masing-masing jenis diantaranya yaitu $D$. draco $6-8 \mathrm{~cm}$, dengan jumlah batang 6 - 10 per rumpun. D. mattanensis $3-6 \mathrm{~cm}$, dengan jumlah batang $4-8$ per rumpun dan $D$. didymophylla $1-3 \mathrm{~cm}$, dengan jumlah batang $3-6$ per rumpun.

Panjang ruas (internode), dari hasil grafik di atas terdapat data kuantitatif yang dilakukan sebanyak < 10 sampel rotan penghasil jernang dengan hasil pengukuran yang berbeda untuk setiap masing-masing jenis diantaranya yaitu $D$. draco $15-40 \mathrm{~cm}, D$. mattanensis 10 - $35 \mathrm{~cm}$ dan D. didymophylla 8 - $30 \mathrm{~cm}$.

Panjang daun, dari hasil grafik di atas terdapat data kuantitatif yang dilakukan sebanyak < 10 sampel rotan penghasil jernang dengan hasil pengukuran yang berbeda untuk setiap masing-masing jenis diantaranya yaitu $D$. draco $30-45 \mathrm{~cm}$, dengan jumlah daun 60 - 70 per batang, D. mattanensis $30-38 \mathrm{~cm}$, jumlah daun $60-70$ per batang dan $D$. didymophylla 26 - $30 \mathrm{~cm}$, jumlah daun 60 - 70 per batang.

Diameter buah, dari hasil grafik di atas terdapat data kuantitatif yang dilakukan sebanyak < 10 sampel rotan penghasil jernang dengan hasil pengukuran yang berbeda untuk setiap masing-masing jenis diantaranya yaitu $D$. draco $4-6 \mathrm{~cm}$, dengan jumlah buah 20 - 40 per tandan, $D$. mattanensis 2 - $4 \mathrm{~cm}$, dengan jumlah buah 18 - 30 per tandan dan $D$. didymophylla 2 - $3 \mathrm{~cm}$, dengan jumlah buah 18 - 28 per tandan.

Panjang duri terpendek, dari hasil grafik di atas terdapat data kuantitatif yang dilakukan sebanyak < 10 sampel rotan penghasil jernang dengan hasil pengukuran yang berbeda untuk setiap masing-masing jenis diantaranya yaitu $D$. draco $1-2 \mathrm{~cm}, D$. mattanensis 1 - $2 \mathrm{~cm}$, dan D. didymophylla 1 - $2 \mathrm{~cm}$. 
Panjang duri terpanjang, dari hasil grafik di atas terdapat data kuantitatif yang dilakukan sebanyak < 10 sampel rotan penghasil jernang dengan hasil pengukuran yang berbeda untuk setiap masing-masing jenis diantaranya yaitu $D$. draco $2-4 \mathrm{~cm}, D$. mattanensis 2 - $3 \mathrm{~cm}$, dan $D$. didymophylla 1 - $2 \mathrm{~cm}$.

\section{Analisis Data Karakter Morfologi Kuantitatif Menggunakan Uji ANOVA Satu Arah dan Uji Lanjut BNt}

Untuk mendapatkan perbedaan morfologi antara tiga spesies rotan penghasil jernang (Daemonorops spp.) dilakukan terlebih dahulu perhitungan data karakter morfologi kuantitatif rata-rata dan standar deviasi pada masing-masing rotan penghasil jernang Daemonorops spp. kemudian di analisis ANOVA dengan taraf 0,05 yang dilihat $\mathrm{F}$ hitung dan $\mathrm{F}$ tabel, jika $\mathrm{F}$ hitung < $\mathrm{F}$ tabel, maka perbedaan tidak signifikan dan jika $\mathrm{F}$ hitung $>\mathrm{F}$ tabel, maka perbedaan terlihat signifikan (Tabel 3.), dan dilanjutkan dengan analisis ANOVA taraf 0,01 untuk melihat perbedaan signifikan yang lebih kecil diantara ketiga jenis rotan penghasil jernang tersebut (Tabel 4.). Setelah dilakukan analisis ANOVA, kemudian karakter morfologi kuantitatif rotan jernang yang menunjukkan hasil berbeda signifikan (Tabel 5.), maka dilakukan uji lanjut BNt untuk dapat dilihat perbedaan secara nyata antara ketiga jenis rotan penghasil jernang Daemonorops spp.

Tabel 3. Analisis ANOVA taraf 0,05 pada karakter morfologi rotan penghasil jernang (Lampiran 2.)

\begin{tabular}{|c|c|c|c|c|}
\hline ANOVA & F hitung & Simbol & F tabel & Ket \\
\hline $\begin{array}{l}\text { Tinggi batang } \\
\text { (m) }\end{array}$ & 25,33 & $>$ & 5,14 & $\begin{array}{l}\text { Perbedaan } \\
\text { signifikan }\end{array}$ \\
\hline $\begin{array}{l}\text { Diameter batang } \\
(\mathrm{cm})\end{array}$ & 10,01 & $>$ & 5,14 & $\begin{array}{l}\text { Perbedaan } \\
\text { signifikan }\end{array}$ \\
\hline $\begin{array}{l}\text { Jumlah batang } \\
\text { (per rumpun) }\end{array}$ & 2,30 & $<$ & 5,14 & $\begin{array}{l}\text { Perbedaan } \\
\text { tidak } \\
\text { signifikan }\end{array}$ \\
\hline $\begin{array}{l}\text { Panjang tandan } \\
\text { (m) }\end{array}$ & 6,33 & $>$ & 5,14 & $\begin{array}{l}\text { Perbedaan } \\
\text { signifikan }\end{array}$ \\
\hline $\begin{array}{l}\text { Panjang ruas } \\
\text { (internode) }(\mathrm{cm})\end{array}$ & 11,37 & $>$ & 5,14 & $\begin{array}{l}\text { Perbedaan } \\
\text { signifikan }\end{array}$ \\
\hline $\begin{array}{l}\text { Panjang daun } \\
(\mathrm{cm})\end{array}$ & 23,89 & $>$ & 5,14 & $\begin{array}{l}\text { Perbedaan } \\
\text { signifikan }\end{array}$ \\
\hline $\begin{array}{l}\text { Jumlah daun } \\
\text { (per batang) }\end{array}$ & 0,33 & $<$ & 5,14 & $\begin{array}{l}\text { Perbedaan } \\
\text { tidak } \\
\text { signifikan }\end{array}$ \\
\hline $\begin{array}{l}\text { Diameter buah } \\
(\mathrm{cm})\end{array}$ & 25,33 & $>$ & 5,14 & $\begin{array}{l}\text { Perbedaan } \\
\text { signifikan }\end{array}$ \\
\hline Jumlah buah (per & 0,32 & $<$ & 5,14 & Perbedaan \\
\hline
\end{tabular}




\begin{tabular}{|c|c|c|c|c|}
\hline tandan) & & & & $\begin{array}{c}\text { tidak } \\
\text { signifikan }\end{array}$ \\
\hline $\begin{array}{l}\text { Panjang duri } \\
\text { terpendek }(\mathrm{cm})\end{array}$ & 0,33 & $<$ & 5,14 & $\begin{array}{l}\text { Perbedaan } \\
\text { tidak } \\
\text { signifikan }\end{array}$ \\
\hline $\begin{array}{l}\text { Panjang duri } \\
\text { terpanjang }(\mathrm{cm})\end{array}$ & 2,60 & $<$ & 5,14 & $\begin{array}{l}\text { Perbedaan } \\
\text { tidak } \\
\text { signifikan }\end{array}$ \\
\hline
\end{tabular}

Tabel 4. Analisis ANOVA taraf 0,01 pada karakter morfologi rotan penghasil jernang (Lampiran 3.)

\begin{tabular}{|c|c|c|c|c|}
\hline ANOVA & $F$ hitung & Simbol & $F$ tabel & Ket \\
\hline Tinggi batang $(\mathrm{m})$ & 25,33 & $>$ & 10,92 & $\begin{array}{l}\text { Perbedaan } \\
\text { signifikan }\end{array}$ \\
\hline Diameter batang $(\mathrm{cm})$ & 10,01 & $<$ & 10,92 & $\begin{array}{l}\text { Perbedaan tidak } \\
\text { signifikan }\end{array}$ \\
\hline Panjang tandan (m) & 6,33 & $<$ & 10,92 & $\begin{array}{l}\text { Perbedaan tidak } \\
\text { signifikan }\end{array}$ \\
\hline $\begin{array}{l}\text { Panjang ruas } \\
\text { (internode) }(\mathrm{cm})\end{array}$ & 11,37 & $>$ & 10,92 & $\begin{array}{l}\text { Perbedaan } \\
\text { signifikan }\end{array}$ \\
\hline Panjang daun $(\mathrm{cm})$ & 23,89 & $>$ & 10,92 & $\begin{array}{l}\text { Perbedaan } \\
\text { signifikan }\end{array}$ \\
\hline Diameter buah $(\mathrm{cm})$ & 25,33 & $>$ & 10,92 & $\begin{array}{l}\text { Perbedaan } \\
\text { signifikan }\end{array}$ \\
\hline
\end{tabular}


Tabel 5. Karakter morfologi kuantitatif nilai rata-rata \pm standar deviasi dan BNt rotan penghasil jernang Daemonorops spp.

\begin{tabular}{|c|c|c|c|c|}
\hline \multirow{2}{*}{ No. } & \multirow{2}{*}{ Karakter Yang Di Uji } & \multicolumn{3}{|c|}{ Nilai Rata-Rata \pm Standar Deviasi dan BNt } \\
\hline & & D. didymophylla & D. mattanensis & D. draco \\
\hline 1. & Tinggi batang $(\mathrm{m})$ & $2,25 \pm 0,46^{a}$ & $3,63 \pm 0,51^{b}$ & $5,50 \pm 0,53^{\mathrm{c}}$ \\
\hline 2. & Diameter batang $(\mathrm{cm})$ & $26,50 \pm 1,77 \mathrm{a}$ & $28,85 \pm 1,06^{b}$ & $34,12 \pm 2,79 b$ \\
\hline 3. & $\begin{array}{l}\text { Jumlah batang (per } \\
\text { rumpun) }\end{array}$ & $4,25 \pm 1,28$ & $6,00 \pm 1,77$ & $8,37 \pm 1,59$ \\
\hline 4. & Panjang tandan $(\mathrm{m})$ & $1,75 \pm 0,46$ a & $2,38 \pm 0,51^{b}$ & $3,12 \pm 0,64{ }^{c}$ \\
\hline 5. & $\begin{array}{l}\text { Panjang ruas (internode) } \\
(\mathrm{cm})\end{array}$ & $59,25 \pm 1,03$ a & $66,00 \pm 5,01 b$ & $98,75 \pm 1,48^{\mathrm{c}}$ \\
\hline 6. & Panjang daun $(\mathrm{cm})$ & $28,50 \pm 1,77$ a & $35,63 \pm 2,72^{b}$ & $43,87 \pm 1,55^{c}$ \\
\hline 7. & Jumlah daun (per batang) & $63,75 \pm 5,17$ & $65,00 \pm 5,34$ & $65,00 \pm 5,34$ \\
\hline 8. & Diameter buah $(\mathrm{cm})$ & $2,62 \pm 0,51$ a & $3,75 \pm 0,46^{b}$ & $5,62 \pm 0,51^{c}$ \\
\hline 9. & Jumlah buah (per tandan) & $22,75 \pm 4,26$ & $25,50 \pm 5,73$ & $29,25 \pm 7,22$ \\
\hline 10. & Panjang duri terkecil $(\mathrm{cm})$ & $1,75 \pm 0,46$ & $1,75 \pm 0,46$ & $1,75 \pm 0,46$ \\
\hline 11. & $\begin{array}{l}\text { Panjang duri terpanjang } \\
(\mathrm{cm})\end{array}$ & $1,75 \pm 0,46$ & $2,50 \pm 0,53$ & $3,25 \pm 0,88$ \\
\hline
\end{tabular}

Hasil analisis data pada tabel di atas terdapat 11 karakter morfologi yang diantaranya ada 5 karakter morfologi yang tidak berbeda signifikan antara ketiga jenis rotan penghasil jernang (Daemonorops spp.) yaitu pada karakter jumlah batang, jumlah daun, jumlah buah, panjang duri terpendek dan panjang duri terpanjang.

Sedangkan 6 karakter yang lain adalah berbeda secara signifikan. Tinggi batang ketiga jenis rotan jernang ini memiliki nilai rata-rata berbeda yaitu $D$. draco 5,50, $D$. mattanensis 3,63, dan D. didymophylla 2,25 yang kemudian ditambahkan dengan nilai Bnt untuk mendapatkan tanda perbedaan pada masing-masing jenis rotan jernang tersebut. Jika tanda yang dikeluarkan ${ }^{\mathrm{a}},{ }^{\mathrm{b}}, \mathrm{c}$, maka dapat diartikan perbedaan terlihat secara signifikan dikarenakan tidak ada keterikatan pada tanda tersebut misalnya ${ }^{a},{ }^{a}{ }^{b} .{ }^{b c}$ yang berarti perbedaan tidak signifikan.

Pengukuran validitas adalah dengan menentukan besarnya nilai $\mathrm{F}$ tabel dengan ketentuan $\mathrm{df}=\mathrm{N}-2$, atau pada kasus penelitian ini karena $\mathrm{N}=8$. Syarat bahwa item-item tersebut valid adalah nilai corrected item total correlation ( $\mathrm{F}$ hitung) lebih besar $\mathrm{F}$ tabel dimana untuk subyek ketentuan $\mathrm{df}=\mathrm{N}-2$ pada penelitian ini karena $\mathrm{N}=8$, berarti 8-2 $=6$ dengan menggunakan taraf 5\% (Sugiono, 2000).

Pada taraf 0,05 terdapat 6 karakter morfologi yang berbeda secara signifikan dan sama halnya dengan percobaan taraf 0,01 terdapat 6 karakter morfologi yang berbeda secara signifikan yaitu pada karakter tinggi batang, diameter batang, panjang tandan, panjang ruas, panjang daun, dan diameter buah. Perbedaan uji ANOVA pada taraf 0,05 dan taraf 0,01 yaitu dilakukan perhitungan sebanyak dua kali, jika pada taraf 0,05 terdapat 6 yang terlihat berbeda siginifikan maka dilakukan kembali perhitungan pada taraf 0,01 agar terlihat lebih jelas nilai perbedaan yang signifikan pada 6 karakter morfologi rotan jernang tersebut. 
Setelah dilakukan uji ANOVA pada taraf kepercayaan 5\%, hasilnya menunjukkan bahwa 6 karakter morfologi memberikan perbedaan signifikan terhadap ketiga jenis rotan penghasil jernang (Daemonorops spp.). Karena uji ANOVA menunjukkan adanya perbedaan yang nyata secara statistik, maka dilakukan uji lanjut BNt untuk mengetahui ada tidaknya perbedaan antar tiap jenis karakter morfologinya. Berdasarkan analisis ANOVA, variabel bebas seperti diameter dan tinggi batang rotan tidak layak dilakukan analisis regresi karena nilai $\mathrm{F}$ hitung $\leq \mathrm{F}$ tabel. Padahal menurut Winarni et. al, (2004) diameter memiliki pengaruh terhadap produksi buah, semakin besar diameter suatu pohon maka produksi buah juga akan meningkat.

Diantara 6 karakter selanjutnya dilakukan uji BNt karena dilihat dari hasil anova menunjukkan adanya perbedaan yang signifikan pada 6 karakter ini, maka perlunya uji BNt ini untuk lebih memastikan perbedaan yang lebih signifikan dari angka terkecil yang dihasilkan. Hasil yang didapatkan terlihat adanya perbedaan yang sangat signifikan antara rotan penghasil jernang ketiga jenis rotan penghasil jernang ini. Simbol menunjukkan hasil beda nyata terkecil yaitu $D$. didymophylla ${ }^{\mathrm{a}}, D$. mattanensis ${ }^{\mathrm{b}}, D$. draco ${ }^{\mathrm{c}}$ pada karakter tinggi batang, panjang tandan, panjang daun, panjang ruas dan diameter buah. Sedangkan simbol pada diameter batang menunjukkan hasil beda nyata terkecil hanya pada jenis $D$. didymophylla ${ }^{\mathrm{a}}, D$. mattanensis ${ }^{\mathrm{b}}$ dan $D$. draco ${ }^{\mathrm{b}}$ tidak menunjukkan beda nyata terkecil pada kedua jenis lainnya. Maksud dari simbola ${ }^{\mathrm{b}},{ }^{\mathrm{c}}$ adalah adanya perbedaan yang signifikan pada karakter morfologi pada ketiga jenis rotan penghasil jernang, dan jika perbedaan tidak signifikan maka simbol yang diberikan akan sama dengan simbol pengujian pada karakter pertama.

Dari hasil perbandingan karakter morfologi jenis rotan penghasil jernang di Jambi yaitu terdapat pada ukuran rotan jernangnya, dimana rotan jernang di Jambi hanya memiliki diameter batang $1-3 \mathrm{~cm}$ sedangkan rotan jernang di Aceh Tengah ini memiliki diameter batang $6-8 \mathrm{~cm}$. Perbedaan lainnya yaitu pada tinggi batang, di Jambi memiliki tinggi batang 8 - $15 \mathrm{~m}$ di Jambi sedangkan di Aceh Tengah 4 - $6 \mathrm{~m}$.

Menurut Rustiami et. al (2004) ciri-ciri yang membedakan Daemonorops draco dengan Daemonorops yang lain adalah Daemonorops draco memiliki tinggi batang $8 \mathrm{~m}-$ $15 \mathrm{~m}$, jarak ruas antar batang $20 \mathrm{~cm}$, dengan pelepah $30 \mathrm{~mm}$. Panjang daun $3 \mathrm{~m}$, sulur 100 $\mathrm{cm}$, tangkai daun $10 \mathrm{~cm}$, dan memiliki duri-duri yang menutup batang.

Daun memiliki pelepah daun yang membentuk berkas melingkar pada batang, kulit buah bersisik mirip salak. Duri-duri batang tersusun sedemikian rupa, yang disebut the knee.

Daemonorops merupakan tumbuhan dioecius, yaitu berupa bunga betina dan bunga jantan ditemukan pada tumbuhan yang berbeda. Daemonorops draco mulai berbuah setelah berumur 2 tahun, namun baru menghasilkan getah jernang setelah berumur 5 tahun. Satu rumpun Daemonorops secara umum terdiri dari 5-10 individu.

Perbedaan yang paling terlihat signifikan dari ketiga jenis rotan jernang ini yaitu pada karakter morfologi diameter batang, karena pada diameter batang, dan warna batang di masing-masing jenis sudah sangat terihat berbeda dan dapat dibedakan langsung yang mana $D$. draco, D. mattanensis dan $D$. didymophylla jika dilihat dari pandangan pertama ketika melihat rotan jernang tersebut.

Ketiga jenis rotan jernang ini yaitu D. draco, D. mattanensis, dan D. didymophylla termasuk kedalam jenis rotan genus Daemonorops (Rustiami 2004) dimana mereka masih 
tergolong dari famili Arecaceae, tetapi menurut Rustiami (2019) yang menemukan spesies baru rotan calamus (Arecaceae; Calamoideae, Calaminae dari Sumatra) bukan termasuk dari genus Daemonorops tetapi masuk ke dalam genus calamus.

\section{KESIMPULAN}

1. Jenis rotan penghasil jernang (Daemonorops spp.) di Kecamatan Kuta Panang memiliki karakter morfologi bersama dan berbeda untuk setiap spesies. Karakter morfologi bersama yaitu perawakannya liana tumbuh memanjat dan berumpun, warna daun hijau, susunan buah bergerombol, posisi duri tegak dan memiliki duri pada tangkai daun sedangkan karakter morfologi berbeda yaitu warna batang, warna buah, sisik buah, dan warna duri.

2. Hasil data kuantitatif pada tinggi batang: D. draco 4 - $6 \mathrm{~m}$, D. mattanensis $2-4$ $\mathrm{m}$, D. didymophylla 1 - $3 \mathrm{~m}$, panjang tandan yaitu $D$. draco 3 - $4 \mathrm{~m}, D$. mattanensis 1 - 3 $\mathrm{m}$, dan D. didymophylla 1 - $2 \mathrm{~m}$. Diameter batang: D. draco $6-8 \mathrm{~cm}, D$. mattanensis 3 - 6 $\mathrm{cm}$, dan D. didymophylla $1-3 \mathrm{~cm}$. Panjang ruas: D. draco $15-40 \mathrm{~cm}, D$. mattanensis 10 $35 \mathrm{~cm}$ dan $D$. didymophylla 8 - $30 \mathrm{~cm}$. Panjang daun: D. draco $30-45 \mathrm{~cm}$, D. mattanensis 30 - $38 \mathrm{~cm}$, dan D. didymophylla 26 - $30 \mathrm{~cm}$. Diameter buah: D. draco $4-6 \mathrm{~cm}, D$. mattanensis 2 - $4 \mathrm{~cm}$, dan D. didymophylla 2 - $3 \mathrm{~cm}$. Panjang duri panjang: D. draco 2 - 4 $\mathrm{cm}, D$. mattanensis $2-3 \mathrm{~cm}$, dan D. didymophylla $1-2 \mathrm{~cm}$.

3. Uji ANOVA yang berbeda signifikan yaitu pada karakter morfologi kuantitatif tinggi batang, panjang diameter batang, panjang tandan, panjang ruas (internode), panjang daun, dan diameter buah menunjukkan hasil yang berbeda signifikan antara ketiga jenis rotan penghasil jernang (Daemonorops spp.), sedangkan karakter morfologi pada jumlah batang, jumlah daun, jumlah buah, panjang duri terpendek, dan panjang duri terpanjang menunjukkan hasil yang tidak berbeda signifikan antara ketiga jenis Daemonorops spp.

4. Uji BNt yang sangat nyata yaitu pada karakter morfologi kuantitatif tinggi batang, diameter batang, panjang tandan, panjang ruas (internode), panjang daun, dan diameter buah.

\section{DAFTAR PUSTAKA}

Gafar, P. A. 2010. Perfoma Teknologi Dan Mutu Jernang Produksi Indonesia. Journal of Industrial Research (Jurnal Riset Industri), 4(3): 37-44.

Grieve, M., 2006. A Modern Herbal V1. United States: Kessinger Publishing. P. 144-148

Januminro. 2000. Rotan Indonesia Potensi Budidaya Pemungutan Pengolahan Standar Mutu dan Prospek Pengusahaan. Kanisius. Yogyakarta.

John, L. (2005). The potential of non number forest products to contribute to rural livelihoods in the windward islands of the Caribbean. (CANARI Technical.

Matangaran, J. R., \& Puspitasari, L. 2012. Potensi dan Pemanenan Buah Rotan Jernang. Jurnal Silvikultur Tropika, 3(1).

Permenhut. 2007. Peraturan Menteri Kehutanan No.: P.35/Menhut II/2007 tentang Hasil Hutan Bukan Kayu. Jakarta.

Rustiami H, Setyowati FM, Kartawinata K. 2004. Taxonomy and uses of Daemonorops draco (Willd.) Blume. Journal of Tropical Ethnobiology 1(2):65-75. 
Sugiono. (2000). Statistika untuk penelitian. Bandung: Alfabeta.

Sumarna, Y. 2004. Budidaya rotan penghasil getah jernang yang dihasilkan dari beberapa jenis. Badan Puslitbang Bogor.

Tjitrosoepomo, G., 2005. Morfologi Tumbuhan. Gajah Mada University. Press Yogyakarta.

Winarni I, Sumadiwangsa ES, Setyawan D. 2004. Pengaruh Tempat Tumbuh, Jenis dan Diameter Batang Terhadap Produktifitas Pohon Penghasil Biji Tengkawang. Jurnal Penelitian Hasil Hutan. 22(1): 23-30. 